\title{
A mecânica do vírus: perspectivas filosóficas
}

\author{
The virus mechanics: philosophical perspectives
}

\section{Luiz Maurício Bentim da Rocha Menezes ${ }^{1}$}

1 Professor de Filosofia Política, Ética e Filosofia da Tecnologia do Instituto Federal de Educação, Ciência e Tecnologia do Triângulo Mineiro (IFTM) E-mail: Imbrmenezes@yahoo.com.br Orcid: http://orcid.org/0000-0003-4925-9876 Lattes: http://lattes.cnpq.br/5932586465926963

RESUMO: Desde o final do ano de 2019, o novo coronavírus (covid-19) vem preocupando a população global devido ao crescente aumento de casos de pessoas infectadas e de mortes causadas pelo vírus. Independentemente do resultado da pandemia, é certo que o mundo não mais será como antigamente. Mas que mundo se formará após a epidemia viral? Esse trabalho tem o intuito de discutir as capacidades que temos para construir o porvir. Isto é, os mundos possíveis ainda não explorados e suas perspectivas diante dos sintomas pelos quais sofremos com o devir. Em nosso artigo, pretendemos explorar as possibilidades filosóficas, antropológicas, econômicas e políticas junto com as novas tecnologias, em uma tentativa de construir uma experiência mental através da analogia com a máquina e sua relação com o mundo.

Palavras-chave: Filosofia Política; Covid-19; Ontologia Política; Filosofia do Mecanismo.

ABSTRACT: Since the end of 2019, the new coronavirus (covid-19) has been worrying global population due to the growing increase of infected people cases and casualties. Regardless of the outcome of this pandemic, it is already acknowledged that the world will not be the same. But what world will be formed after this viral epidemic? The present work aims to discuss the capabilities we hold to build the future. Thusly, the possible worlds that have not yet been explored and their perspectives facing the symptoms from which we will suffer henceforth. In this paper, we aim to explore the philosophical, anthropological, economic, and political possibilities altogether with new technologies, to build a mental experience through the analogy with the machine and its relationship with the world.

Keywords: Political Philosophy; Covid-19; Political Ontology; Mechanical Philosophy.

A peste fala: Eu reino, é um fato, logo um direito. No entanto, um direito não se discute: vocês têm de se adaptar.

[...] Seu rei tem as unhas negras e o uniforme sóbrio. Não reina, sitia. Seu palácio é um quartel; seu pavilhão de caça, um tribunal. Fica proclamado o estado de sítio.

[....] Em resumo: trago o silêncio, a ordem, e a justiça absoluta.

Não espero agradecimentos, o que faço por vocês é natural. Mas exijo colaboração ativa. Meu ministério começou.

(Albert Camus. Estado de Sítio)

\section{Introdução}

O novo coronavírus (covid-19) ganhou destaque no final do ano 2019 através da intensa contaminação da população da China, mais especificamente na região de Wuhan. O vírus ganhou seu nome científico de SARS-CoV-2 (Coronavírus da síndrome respiratória aguda grave 2) e tem um alto nível de contágio. A Organização Mundial da Saúde (OMS) definiu que a doença respiratória provocada pela infecção do novo coronavírus deverá ser chamada de Covid-19. O nome da doença resulta das palavras "corona", "vírus" e 
"doença” com indicação do ano em que surgiu (2019). O contágio ganhou dimensões globais em 2020 e não demorou muito para que a OMS declarasse que vivíamos uma forte pandemia em todo o mundo. Aos poucos cidades, estados e países começaram a fechar suas fronteiras e a restringir a locomoção das pessoas, recomendando, ou até mesmo decretando, que as pessoas fiquem em casa para evitar a disseminação do vírus entre as pessoas, em uma tentativa de achatar a curva de contaminação.

Tais medidas foram determinantes para limitar o livre-comércio, afetando seriamente a economia dos países e os dogmas liberais anteriormente defendidos. O mundo passa por uma forte desaceleração e os índices de crescimento global são negativos. Isso levou ao crescente aumento de mensagens nas redes sociais sobre o coronavírus, sendo que algumas dessas são fake news, o que prejudica muito o conhecimento sobre a pandemia que nos assola. Entre pesquisas científicas reais, falsas pesquisas, tratamento indevido, teorias conspiratórias etc., bastante coisa tem sido dita sobre o vírus, suas causas e consequências. Ainda há muita discussão com relação às medidas impostas pela maioria dos governos. Os principais chefes de Estado determinaram o confinamento como a medida mais segura para evitar um agravamento do número de casos da doença, o que poderia facilmente saturar o sistema de saúde dos países e levar milhares à morte. O vírus causa insuficiência respiratória e, em casos mais graves, pode ser necessário o uso de respiradores mecânicos para manter as pessoas infectadas vivas. Por outro lado, as medidas de emergência podem ser interpretadas como exageradas e acima da necessidade exigida. Dessa forma, os governantes poderiam ser acusados de se aproveitarem da crise viral para instaurar um Estado de exceção em seus governos, de maneira a limitar a liberdade de seus cidadãos e impor medidas preventivas em favor do coletivo contra o indivíduo.

Independentemente do resultado da pandemia, é certo que o mundo não mais será como antigamente. Mas que mundo se formará após a epidemia viral? Esse trabalho tem o intuito de discutir as capacidades que temos para construir o porvir. Isto é, os mundos possíveis ainda não explorados e suas perspectivas diante dos sintomas pelos quais sofremos com o devir. Em nosso artigo, pretendemos explorar as possibilidades filosóficas, antropológicas, econômicas e políticas junto com as novas tecnologias, em uma tentativa de construir uma experiência mental através da analogia com a máquina e sua relação com o mundo ${ }^{1}$.

\section{A máquina humana: o cogito virtual}

Estamos passando por uma mudança séria do controle pelo virtual enquanto estamos com medo do real. Trocamos o real pelo virtual definitivamente com esta crise. É possível mudar isso? Quais são as perspectivas de mudança? Quando Descartes meditou sobre o problema do cogito, ele verificou que este seria a sua primeira certeza perante as muitas dúvidas que havia até então levantado. O "eu penso, logo sou” (ego cogito, ergo sum) é a certeza que dá a primeira dimensão sobre conhecer algo que, no caso, seria a si mesmo.

\footnotetext{
${ }^{1}$ Para a construção deste artigo, utilizamos diversas leituras pesquisadas em diferentes sítios da internet. Citamos abaixo a autoria para que possam servir como consulta aos nossos possíveis leitores. A referência completa encontrase no final do artigo. Autores: ACCOMINOTTI; ACOSTA; ADAM; AHMED; AMADEO; ANG; APPELBAUM; ARBIX; BAELE; BENJAMIN; BISCOP; BRACERO; BREÑA; BROOKS; BRUM; BUITER; CABRERA; CAETANO; CAYLEY; CHIN; CHOMSKY; CLOUET; COHEN; DAVIS; DAY; DRYZEK; EAVES; ESCOBAR; FERNANDES; FILDES; FREIRE; GRIFFIN; GURGEL; HARVEY; HARWELL; HEDIDAR; HEER; HORVAT; HU; IYER; KEANE; KEYNES; KHAMSI; KISSLER; KLEIN; LACOMBE; LAMBERT; LAPAVITSAS; LATOUR; LOPES; MAGALHÃES; MBEMBE; MOODY; MOORE; MOREIRA; MOURA; NELSON; O'CONNELL; O'CONNOR; OZKIRIMLI; ÖZSU; PETTY; PICKARD; PIRONE; POWELL; PUTZ; REZENDE; ROBERTS; SABADELL; SAFATLE; SANDERSON; SANDES; SANTIAGO; SCHAMA; SIGNORELLI; SILVEIRA; STOLLER; STROPASOLAS; SWEEZY; TALIANO; TEWARI; TONBY; TORERO; TOURAINE; VASQUEZ; WALKER; WALLACE; WHYTE; WHO; YINENG; YOSHIDA; YUEN; ZEROFSKY; ZIMMERMANN; ZIZEK.
} 
Ter a percepção pelo próprio pensamento de sua existência é a ideia fundamental, já que para pensar é preciso ter um eu que pensa. Diante da clareza do cogito, Descartes percebeu que há uma estreita relação entre o pensamento e o mundo, sendo que eu só posso conhecer o mundo se for através da clareza do meu pensamento. O grande problema que se faz, portanto, não é a existência do mundo como algo real, mas se a minha capacidade de pensar é capaz de conceber o mundo tal qual ele é ou, em outras palavras, se o mundo é, de fato, pensável.

Para isso, Descartes propôs uma metafísica mecanicista para o mundo, isto é, tudo no mundo seria regido pelo princípio que nos diz que “as leis da natureza são as leis da mecânica”. É preciso reduzir a natureza ao cálculo que eu faço, transformar as leis da natureza em leis acessíveis pela razão, eis a proposta da filosofia do mecanismo. O mecanicismo é, portanto, uma teoria que visa explicar os fenômenos naturais pela sua uniformização em modelos inspirados no funcionamento das máquinas. Seguindo esse princípio, temos o estabelecimento da analogia animal-máquina, que nos permitiria entender a natureza a partir do autômato, que seria qualquer tipo de objeto criado pelo humano capaz de explicar a criação natural. Para isso, o mecanicismo se utiliza de regras matemáticas muito precisas com a finalidade de ser um instrumento de análise e interpretação do mundo.

Essa eliminação da fronteira entre o animal (produto da natureza) e o autômato (produto da técnica), na qual se situa significativamente a concepção do corpo-máquina, propicia a constituição de um princípio de tecnicidade, segundo o qual todas as funções orgânicas dos corpos animais e humanos que são explicitadas mecanicamente podem ser artificialmente reproduzidas por máquinas ou, mais brevemente, tudo o que é explicado mecanicamente na natureza pode ser reproduzido artificialmente pela técnica e, desse modo, controlado, corrigido, melhorado, aperfeiçoado. (MARICONDA, 2018, p. 34)

Dessa forma, qualquer corpo poderia ser comparado à máquina, apesar de Descartes ter excluído essa possibilidade para humanos devido ao cogito e a separação dicotômica entre substância pensante e substância corpórea. No presente trabalho, pretendemos retomar essa analogia com a máquina e o mecanismo a partir da nova configuração do pensamento através das novas tecnologias. O distanciamento social pelo qual a maioria das pessoas passa devido à pandemia do vírus covid-19, fez com que a conexão do pensamento com o real se perdesse e se transportasse para o virtual. As redes sociais e novas tecnologias se tornaram o meio pelo qual o pensamento divaga, perdendo o seu contato com o 'mundo lá fora'. Uma espécie de cogito virtual se constituiu e somente através dele passamos a ter contato com as outras pessoas. O pensamento se diluiu na internet e ganhou fluidez capaz de confundir a localização do sujeito pensante. O que chamamos aqui de cogito virtual não tem relação direta com a inteligência artificial, embora não a exclua. $\mathrm{O}$ cogito virtual é uma nova faceta do sujeito humano ao interagir a maior parte do seu tempo com a máquina virtual. O cogito virtual é, portanto, a fusão entre o sujeito pensante cartesiano e sua interação direta com a rede. Um novo solipsismo cartesiano se fez com isso, de modo que o cogito, isto é, o ato de pensar, se realiza apenas virtualmente, o que nos lembra do início do conto de Forster, The Machine Stops:

Uma campainha elétrica toca. A mulher tocou numa chave e a música silenciou. "Eu suponho que preciso ver quem é", pensou, e pôs sua cadeira em movimento. A cadeira, como a música, era operada por mecanismos e levou-a para o outro lado do quarto onde a campainha ainda tocava importunamente. "Quem é?" ela chamou. Sua voz estava irritada, pois tinha sido interrompida muitas vezes desde que a música começara. Ela conhecia vários milhares de pessoas, em certas direções as relações humanas haviam avançado enormemente. (FORSTER, 2011, p. 248. Grifos nossos)

Independentemente do fim que iremos tomar com essa pandemia, o conto tem um início muito 
parecido com o nosso presente: avançamos muito na velocidade e capacidade de se conhecer milhares de pessoas através das máquinas e artefatos tecnológicos, os mecanismos são muitos e as operações se tornaram fáceis demais, porém isso nos deixou cada vez mais distante fisicamente das pessoas, até mesmo daquelas que conhecemos mais proximamente. O confinamento exigido das pessoas fez com que o processo de virtualização se intensificasse ainda mais, pois, uma vez que as pessoas não poderiam mais se encontrar fisicamente, passaram a utilizar ainda mais as redes sociais. É o fim do corpo como o conhecemos, sua estrutura física foi transferida para avatares virtuais que vagueiam pela rede. Como no conto de Forster, a própria noção de espaço sumiu, já que as pessoas se mantêm em casa, interagindo somente pela internet. Somado a isso, houve um aumento do número de pessoas trabalhando em casa (home office), assim como cursos de Ensino a Distância (EaD). Tudo isso sem se avaliar o problema pelo viés político, social, econômico, logístico e educacional. Não sabemos o que está por vir, como será a situação do Brasil amanhã, como estará a saúde de alunos, trabalhadores e pessoas em geral. Há uma situação de insegurança muito grande entre pessoas próximas e familiares. Alguns não se sentem seguros, outros estão psicologicamente desestabilizados. A falta de preparo não é somente por conta do virtual em si. Há muito mais em jogo aqui do que pode parecer. Estamos atravessando um período de readaptação que vai para além de uma mera adequação ao sistema online.

Isso nos fez refletir ainda mais sobre o significado desse distanciamento social e a intensificação das relações virtuais. Seria um novo tipo de individualismo através de um partilhamento virtual sem levar mais em conta o convívio com o outro em sua materialidade? O mundo está lá fora, apesar de nós, e não será menos se deixarmos de existir. Entre real e virtual, a peste nos trouxe um novo dualismo metafísico, que também pode ser chamado de dualismo contemporâneo. Mas o que seria o dualismo?

Dualismo é uma concepção filosófica que tende a explicar a realidade dividindo-a em dois campos distintos, de maneira que possa explicar as contradições ou diferenças existentes. Um clássico exemplo de dualismo é a teoria platônica sobre o mundo, em que haveria o campo da sensibilidade, passível de mudança e, por isso, perecível e incognoscível; e o campo da inteligibilidade, imutável, eterno e cognoscível. Platão irá chamar os objetos do campo inteligível de "formas" ou "ideias", sendo esses objetos o que há de mais real no mundo. Há nessa distinção uma hierarquia própria, sendo os objetos inteligíveis ontologicamente anteriores e a causa que explica epistemicamente os objetos sensíveis. Em resumo, podemos dizer que forma/ideia é a unidade inteligível da multiplicidade do sensível. De maneira que para cada conjunto de coisas existente no mundo existe uma essência única. Exemplo: todas as cadeiras existentes no mundo têm a mesma essência inteligível de ser cadeira e, por isso, o conceito de cadeira pode ser inteligido pelo intelecto sem que para isso precisemos de nenhuma cadeira sensível. Alguns irão chamar a teoria platônica de "teoria dos dois mundos", no entanto, apesar de bastante comum nos manuais de filosofia (por ser mais fácil de explicar), consideramos equivocada essa denominação, pois Platão está pensando a dicotomia existente no próprio mundo, não dividindo este. Feito esses esclarecimentos, voltemos à crise.

Uma vez que deixamos o real e passamos apenas a viver o virtual, criamos um novo dualismo metafísico entre os objetos virtuais e os objetos mundanos. Estamos imersos cada vez mais no meio virtual, o que aumentou consideravelmente com a pandemia de covid-19. O real foi deixado de lado pela a maioria das pessoas e entregue aos governos para comandar as nossas vidas e determinar como devemos agir diante da crise viral que nos assola. Alguns chegaram a usar a alegoria da caverna de Platão para dizer que não devemos deixar a Caverna, mas permanecer nela para a nossa própria segurança. Ousar sair seria perigoso, pois poderíamos nos contaminar com o novo coronavírus. No entanto, isso é uma jogada dos políticos contra as massas, fazendo-as acreditar nas sombras e imagens como sendo a verdade sobre os objetos que, 
de fato, são usados para nos manipular. Desse modo, as massas não são capazes de perceber que a Caverna é a maneira pela qual os políticos exercem controle sobre a maioria, cerceando sua liberdade e determinando como se deve viver. Em relação à imagem da Caverna, a metáfora é imprecisa se pensarmos que Platão nos diria para ficar na caverna. Não parece que essa seria a mensagem de Platão, caso ele pudesse nos dizer algo sobre a pandemia. A caverna é o próprio vírus: sensível, mutável e mortal. O campo inteligível, que se encontra fora da caverna não tem vírus, pois inclui somente o que sempre é: o Bem, valor máximo e anhipotético. É preciso, portanto, confrontar o signo da caverna, que representa a própria ignorância, e buscar na realidade a verdade sobre as coisas do mundo.

Os governantes estão a fazer de seus governos suas próprias cavernas, isto é, bolhas virtuais em que podem facilmente instaurar a dominação, o controle e a exceção como regra para melhor manipular os cidadãos e fazer deles marionetes sobre o seu domínio. O vírus, apesar de toda a sua periculosidade, nada mais é do que um meio para realizar o real fim de dominação dos governantes. Contra isso, é preciso que saiamos da Caverna e resgatemos o real!

Mas antes precisamos compreender que a máquina que move a máquina humana e manipula o seu pensamento é a máquina econômica e política. Essa máquina é aquela que controla as leis do Mercado e todas as transações existentes nele, conforme iremos analisar a seguir.

\section{A máquina da economia política: o fỉm da mão invisível}

De princípio, diríamos que estamos vivendo uma nova crise do individualismo liberal retratado no neoliberalismo atual. No entanto, não vemos nenhuma luta organizada pela destruição do capitalismo. No fundo, acreditamos que o capitalismo sairá fortalecido dessa crise e com os seus valores acentuados. Apesar da derrocada do Mercado, o assunto na economia ainda é salvar as empresas. Uma espécie de darwinismo econômico está em ação. Deve-se salvar aqueles que forem mais viáveis, economicamente falando. Em outras palavras, uma seleção econômica e artificial (não mais natural), em que ficam os mais aptos para a economia global. Vidas não tem valor em outro sentido para esse sistema. Isso ficou muito claro na declaração oficial do presidente do Brasil em 24 de março, quando não tratou seriamente sobre a doença. O resultado é que o Brasil está cada vez mais próximo de se tornar o epicentro da pandemia. No momento em que escrevemos este artigo, o Brasil ocupa o $2^{\circ}$ lugar em número de infecções por covid-19 no mundo, ultrapassando a marca de um milhão de casos confirmados ${ }^{2}$, atrás apenas dos EUA, e o $5^{\circ}$ país do mundo a registrar mais de mil mortes de covid-19 em um dia (SANDES, 2020), números esses assustadores. Não podemos simplesmente readaptar a rotina do trabalho e dizer que "tudo vai ficar bem". Tudo mudou e não será mais o mesmo desde então.

Em editorial de 03 de abril de 2020, o Financial Times, jornal publicado no Reino Unido, disse que o "vírus expõe a fragilidade do contrato social". Defende com isso uma maior intervenção do Estado na economia e medidas que possam assegurar o bem-estar da população, reduzindo as desigualdades geradas pela pandemia. E conclui:

Reformas radicais - invertendo a direção política predominante das últimas quatro décadas - precisarão ser colocadas sobre a mesa. Os governos terão que aceitar um papel mais ativo na economia. Eles devem ver os serviços públicos como investimentos, e não como passivos, e procurar maneiras de tornar os

\footnotetext{
2 Segundo o site G1, em 29/06/2020 (data do fechamento deste artigo) o país tinha 1.370 .488 casos confirmados de Covid-19.
} 
mercados de trabalho menos inseguros. A redistribuição estará novamente na agenda; os privilégios dos idosos e ricos em questão. As políticas até recentemente consideradas excêntricas, como renda básica e impostos sobre a riqueza, terão que estar na mistura. (THE EDITORIAL BOARD, 2020)

O contrato social, em resumo, é a teoria que defende que há um contrato primordial entre governantes e governados em uma espécie de poder fundador do Estado. A teoria do contrato social teve forte recepção no pensamento filosófico moderno e podemos atribuir à filosofia política de Thomas Hobbes o amadurecimento e a disseminação dessa teoria de grande contribuição para o pensamento político posterior. Partindo de um problema do direito natural, Hobbes irá identificar a vontade ilimitada de poder nas paixões humanas e a disputa constante entre os homens no estado de natureza. Será partindo dessa observação que ele verá a necessidade de um poder superior que regule essas paixões. O Estado é fruto desse poder e terá sua gênese na paixão do medo da morte violenta existente em todos os homens. Visto isso, será o medo que levará os homens a cederem seus poderes (direito a todas as coisas) através de um contrato que irá permitir a formação desse poder maior que é o corpo político (Estado). Estabelecido o contrato, caberia ao Estado Soberano a garantia da vida das pessoas através do estabelecimento dos direitos e deveres dos cidadãos. Para Hobbes, o Estado é o mais perfeito artifício criado pelo homem e representa a união de todos os homens juntos. Sua criação, apesar de não ser natural, se faz por analogia à natureza. Enquanto os homens possuem corpos físicos dados pela natureza, o Estado é o corpo político criado a partir da arte humana (HOBBES, 2008, p. 112). Faz-se a necessidade de se determinar os meios para a constituição da sociedade civil.

Os fundamentos, para a construção do corpo político, se dão através de um pacto de todos os homens com todos os homens para a formação de um terceiro, isto é, o soberano. O pacto não é feito entre o povo e o soberano, pois as pessoas não possuem nenhuma unidade para serem chamadas de 'povo' antes da existência da sociedade, assim como, o soberano só passa a existir depois do pacto. O soberano, portanto, não faz parte do pacto, pois foi formado a partir deste, e, devido a isso, não tem de responder pelo pacto que foi formado. O soberano é a representação do corpo político e o seu poder é chamado de poder soberano e este consiste no poder e na força que cada um dos membros lhe transferiu por meio do pacto (HOBBES, 2010, p. 76). O poder soberano tem três principais características:

(i) ele é irrevogável - nenhum dos contratantes do pacto pode revogá-lo, pois uma vez que todos cederam seus direitos ao soberano, somente ele teria o poder para destituir o corpo político.

(ii) ele é ilimitado - o poder soberano é o maior poder que os homens podem atribuir a outros homens. O poder é absoluto porque se outro poder o limitasse, o soberano seria o poder limitador e não o limitado.

(iii) ele é indivisível - pelo mesmo motivo o poder soberano não pode ser dividido, pois seria uma maneira de limitá-lo.

Segundo Hobbes, as leis civis baseiam-se nas leis naturais, leis estas que conduziriam ao pacto instaurador do Estado como poder soberano. A justiça como um quesito da moralidade é derivada do requerimento moral de procurar a paz. A justiça é considerada um requerimento moral porque a transferência de direitos é um meio de fazer a paz, e direitos são transferidos através de contratos, sendo a justiça um meio de manter os contratos.

Desde o advento do liberalismo econômico com Adam Smith que podemos ver a fragilidade imposta ao Estado para que esse não intervenha na economia. A chamada mão invisivel smithiana nos coloca o preceito de que o mercado seria autorregulável e, portanto, não precisaria de nenhum tipo de intervenção. Dessa forma, o Estado soberano deveria ser reduzido ao mínimo possível, como explica Smith: 
De acordo com o sistema de liberdade natural, o soberano só tem três tarefas a atender; três tarefas de grande importância, de fato, mas simples e inteligíveis ao entendimento comum: primeiro, a tarefa de proteger a sociedade da violência e invasão de outras sociedades independentes; segundo, a tarefa de proteger, tanto quanto possível, todo membro da sociedade da injustiça ou opressão de qualquer outro de seus membros, ou a tarefa de estabelecer uma exata administração da justiça; e terceiro, a tarefa de erigir e manter certas obras públicas e instituições públicas que nunca seria do interesse de nenhum indivíduo, ou pequeno número de indivíduos, erigir e manter, porque o lucro nunca pagaria a despesa a qualquer indivíduo ou pequeno número de indivíduos, se bem que frequentemente façam mais do que compensar para uma grande sociedade. (SMITH, 2017)

Isto quer dizer que o Estado, na visão de Smith, deveria ser reduzido a três atribuições básicas:

1. Defesa - através da polícia e forças armadas.

2. Contratos - para o estabelecimento da justiça através dos contratos civis.

3. Administração - através do sistema público burocrático.

Posteriormente, com o surgimento do neoliberalismo no século XX, temos uma intensificação das regras do mercado sobre o poder político. Medidas de austeridade são a norma, e o mercado financeiro ganha cada vez mais força. As empresas dominam o legislativo com seus lobistas e se aumentam as medidas econômicas que beneficiam o sistema bancário. O bem-estar social diminui e o Estado perde o domínio sobre as decisões socioeconômicas. A crise imposta ao Estado social pela lógica neoliberal não é recente e nem tem como causa o coronavírus. O desmonte estatal já vem sendo praticado há tempos pelos governos, de maneira que vemos como um grande cinismo o editorial do Financial Times citado acima. O contrato social foi enfraquecido por um longo tempo e agora não será fácil recuperar o poderio estatal frente aos ditames do mercado.

No início do século XX, Keynes foi um dos economistas que viu a falência do liberalismo como modelo econômico e o seu "laissez-faire", de maneira que a fórmula smithiana da "mão invisível” que regularia o interesse dos indivíduos seria insuficiente para levar ao crescimento geral do Estado. Abaixo colocamos a explicação de Keynes sobre o liberalismo:

Por volta da época em que a influência de Paley e seus semelhantes estava diminuindo, as inovações de Darwin abalaram os fundamentos da fé. Nada poderia parecer mais contrário do que a antiga doutrina e a nova - a doutrina que encarava o mundo como obra do divino relojoeiro, e a doutrina que parecia extrair tudo do Acaso, do Caos e do Passado Remoto. Mas, neste ponto, as novas ideias iam ao encontro das antigas. Os economistas ensinavam que a riqueza, o comércio e a maquinaria provinham da livre competição, e que a livre competição construíra Londres. Contudo, os darwinistas puderam avançar um pouco mais - segundo eles, o próprio homem resultara da livre-concorrência. O olho humano não era mais a demonstração de um desígnio, capaz de coordenar milagrosamente e da melhor maneira todas as coisas; ele era a suprema realização do acaso, funcionando sob condições de livre concorrência e de laissez-faire. O princípio de sobrevivência do mais apto poderia ser encarado como uma ampla generalização da economia ricardiana. À luz desta síntese, as interferências socialistas tornaram-se não apenas ineficientes, mas ímpias, como se fossem calculadas para retardar o movimento progressivo do poderoso progresso pelo qual nós, como Afrodite, tínhamos emergido do lado primitivo do oceano. (KEYNES, 1984, p. 109-110)

O economista David Ricardo, outro grande desenvolvedor das ideias liberais, era amigo de Thomas Malthus, que teria escrito o famoso Ensaio sobre a População, no qual defendeu a teoria para o controle do aumento populacional e que ficou conhecida como malthusianismo. Charles Darwin foi ávido leitor de Malthus e desenvolveu suas ideias na Origem das Espécies baseadas na teoria malthusiana. As ideias de Darwin foram revolucionárias para a maneira como tomamos a evolução dos animais atualmente. Deixamos o 
modelo do design inteligente, que tomava o mundo pelo viés teleológico, entendendo que o mundo tem uma determinação racional que explica a sua criação, sendo esse mesmo ser racional a causa final de todo o processo do mundo, para adotarmos o modelo evolutivo, em que as espécies não têm uma determinação racional, mas estão em pleno processo de mudança evolutiva. É também certa a utilização de Darwin não apenas na biologia, mas na economia. Levantamos a hipótese de que a "seleção natural" continua a ser a teoria principal para pensar o fator biológico, justamente pela sua utilidade econômica. Ou seja, a sua validação na biologia nada mais é do que uma justificativa para utilizar essa teoria na economia. Segundo Dardot e Laval (2016), a leitura de Darwin influenciará Herbert Spencer a escrever em sua obra Princípios da Biologia a famosa expressão "sobrevivência dos mais aptos", que teria uma correspondência à expressão "seleção natural” cunhada por Darwin. Posteriormente, o próprio Darwin acrescentaria a expressão de Spencer, a partir da sexta edição de $A$ origem das espécies de 1872, deixando clara a relação entre os termos (DARWIN, 2018).

Convém sublinhar a virada que o pensamento de Spencer representa na história do liberalismo. O ponto decisivo que permite a passagem da lei da evolução biológica para suas consequências políticas é a prevalência na vida social da luta pela sobrevivência. Sem dúvida, a referência a Malthus ainda é muito importante em Spencer: nem todos os homens são convidados para o grande "banquete da natureza". À essa influência, porém, somou-se a ideia de que a competição entre os indivíduos constituía para a espécie humana, que nisso é assimilável às outras espécies, o próprio princípio do progresso da humanidade. Daí a assimilação da concorrência econômica a uma luta vital geral, que é preciso deixar que se desenvolva para que a evolução não seja interrompida; daí as principais consequências que examinamos antes, em especial as que condenavam a ajuda aos mais necessitados, que deveriam ser abandonados à própria sorte. (DARTOT; LAVAL, 2016)

As teorias de Spencer aplicadas à sociedade levaram ao desenvolvimento do termo 'darwinismo social' para se referir a esse processo de seleção econômica análogo ao processo de seleção natural observado por Darwin na natureza. O spencerismo levou ao aprimoramento do ultraindividualismo neoliberal. Mas o caso se inverte quando envolve o sistema financeiro. Assim como na crise de 2008, a atual crise causada pelo coronavírus levou a consequências catastróficas para o mercado financeiro. Isso fez com que os governos emitissem dinheiro para salvar seus bancos (ACOSTA, 2020). O capitalismo é um sistema que preserva sempre o banqueiro, fazendo com que o resto da população fique refém do sistema bancário. É um pouco do "salve o rei" no antigo regime, pois o rei era o centro do modelo que dominava aquela época. Agora, no liberalismo/neoliberalismo o centro é o burguês, sendo que o principal burguês desse modelo é o banqueiro (pessoa) representando o banco (instituição privada ou pública). Quem é o rei tanto faz, já diria Hobbes, pois o que realmente interessa é ter alguém no poder mantendo a soberania do Estado. No modelo burguês, os Estados precisam salvar o banqueiro, isto é, o 'novo rei' do modo de produção que vivemos. Como o Banco Central salva os bancos em geral, os banqueiros acabam assumindo novos riscos ainda mais perigosos. Ou seja, os banqueiros sabem que serão salvos em épocas de crise. Dessa forma, as crises nunca são problemas para os banqueiros, apenas para a população. Os bancos são uma espécie de intocáveis, pois são o "coração do sistema capitalista". Nesse momento, devemos nos fazer duas perguntas: 1. Há melhor momento para se derrubar o capitalismo senão em uma crise? Tudo indica que o momento mais propício para se acabar com o capitalismo é quando este se apresenta em crise. 2. Devemos salvar esse sistema? Se desejarmos permanecer no capitalismo a resposta é sim. Se desejarmos acabar com o capitalismo, a resposta é não. Que os bancos são o coração do sistema isso é dito por Marx. Acabar com o sistema de crédito que beneficia banqueiros através do capital fictício, conforme o livro 3 do Capital (MARX, 2017), é essencial 
para acabar com o capitalismo. Na época de Marx, o padrão ouro ainda estava em vigor e todo dinheiro era lastreado em ouro. No entanto, segundo David Harvey, Marx percebeu que

um sistema monetário baseado puramente em mercadorias-dinheiro age como uma barreira ao avanço da acumulação do capital, porque há uma quantidade limitada de dinheiro à disposição. Há um perigo claro e constante daquilo que hoje chamamos de "repressão financeira", que ocorre quando não há dinheiro suficiente (de nenhum tipo) para fazer circular o volume crescente de mercadorias que são produzidas à medida que avança a acumulação do capital. As moedas de crédito se tornam, portanto, não só necessárias, mas cruciais para a expansão contínua do capitalismo. (HARVEY, 2014, p. 232)

No início da pandemia, enquanto petróleo e outras commodities despencavam no mercado financeiro, o ouro se manteve em alta. A moeda utilizada nos Estados é baseada no sistema de crédito e, portanto, tem sua confiança garantida nos títulos que emite, já que não é lastreada em nenhum metal. Mas em épocas de crise, se procura confiar novamente nos metais ao invés dos títulos emitidos pelo tesouro, pois, de acordo com Marx,

o crédito, sendo [...] uma forma social de riqueza, desloca o dinheiro e usurpa sua posição. É a confiança no caráter social da produção que faz com que a forma-dinheiro dos produtos apareça como algo meramente evanescente e ideal, como uma mera noção. Mas tão logo o crédito é abalado, e essa é uma fase regular e necessária no ciclo da indústria moderna, supõe-se que toda riqueza real é efetiva e repentinamente transformada em dinheiro, em ouro e prata - uma demanda insana, mas que surge necessariamente do próprio sistema. E o ouro e a prata necessários para satisfazer essa imensa demanda atingem o valor de alguns milhões no cofre do banco. (MARX, 2017, p. 708)

Mesmo não conhecendo a moeda fiduciária, Marx conseguiu prever o quanto o capitalismo precisaria se libertar da moeda-mercadoria para continuar a crescer indefinidamente, apesar de demonstrar o quanto esse crescimento exponencial seria um problema para o próprio capitalismo justamente pelo caráter usurpador do crédito. Ou seja, a moeda que não é baseada em nada além de títulos do tesouro, é uma moeda mais volúvel. Por um lado, isso possibilita um crescimento indefinido da economia, por outro lado, é um capital mais incerto e volátil, capaz de criar bolhas especulativas que podem vir a estourar a qualquer momento e causar uma crise da economia global, como o caso da crise de 2008, por exemplo. Segundo a linguagem marxiana, o crédito intensifica ainda mais a produção do mais-valor, isto é, o valor que é produzido em cima da força de trabalho não paga. Nos Manuscritos, Marx dirá que

Numa sociedade que se encontra em crescente prosperidade, apenas os mais ricos entre todos podem viver do juro sobre o dinheiro. Todos os outros obrigam-se, com o seu capital, a montar um negócio ou lançá-lo no comércio. Desta maneira, a concorrência entre os capitais torna-se, portanto, maior, a concentração dos capitais torna-se maior, os grandes capitalistas levam à ruína pequenos, e uma parte dos capitalistas de outrora baixa à classe dos trabalhadores, a qual, com esta entrada, sofre, em parte, novamente uma redução do salário e cai numa dependência ainda maior dos poucos grandes capitalistas. (MARX, 2004, p. 26-27)

A sociedade capitalista é uma sociedade inerentemente desigual. Em nome da liberdade econômica, os liberais se apoiam em uma farsa só posta às claras com uma crise. É o momento de se construir um novo contrato social para o bem da população. Esse deve ser um contrato cidadão, que respeite em primeiro lugar o povo e retire do mercado as decisões soberanas da nação. Como nos lembra Hobbes em seu Leviathan, o medo é um motivo legítimo para se estabelecer um contrato. O contrato social tem um novo inimigo, mas um velho medo, sendo este o medo da morte. É sobre esse afeto que devemos agora montar os arcabouços 
morais que irão assegurar à população o direito básico da vida.

\section{A máquina ética: o anel invisível}

Em que consiste a máquina ética que move o nosso sentimento moral ou a nossa razão prática para as determinações que envolvem todas as relações com outras pessoas? Em uma sociedade que reduziu a vida cotidiana ao campo virtual, faz com que o ser real que somos se torne um ser socialmente invisível e virtual, perdendo toda a sua atualidade a vagar através da internet sem nenhum destino ou lugar certo. É preciso fazer o visível invisível e o invisível visível. Isso nos lembra de um mito, o mito do anel de Gyges presente no Livro II da República de Platão ${ }^{3}$.

Com o intuito de que Sócrates demonstre que a justiça é um bem em si mesmo e por suas consequências, Gláucon irá lançar um desafio a Sócrates para que este prove que é melhor ser justo do que injusto em qualquer possibilidade contrafactual (Rep., 357b). O mito do anel de Gyges vem retratar justamente uma dessas possibilidades contrafactuais em que a injustiça parece ser superior à justiça. Diz o mito que Gyges era um pastor da Lídia, região da Ásia Menor, e que cuidava do rebanho do rei quando presenciou um forte terremoto. O terremoto abriu uma fenda bem onde Gyges tomava conta do rebanho. Sentindo curiosidade, resolveu descer pela fenda e chegou a um lugar repleto de maravilhas e riquezas. Dentre essas, viu um cavalo de bronze oco e dentro deste estava um cadáver de um homem nu, tendo apenas um anel de ouro na mão. Gyges pegou o anel e saiu da caverna em que estava. Mais tarde, reunindo-se com os demais pastores, ele deu um giro com o engaste do anel para dentro da palma da mão e ficou invisível. Depois deu um novo giro no engaste e ficou novamente visível. Percebendo que tinha o poder de ficar visível e invisível quando tivesse vontade, resolveu corromper a rainha para ajudá-lo a matar o soberano da Lídia. Feito isso, Gyges passou a ser o novo soberano da Lídia.

O anel de Gyges é, portanto, um anel de poder capaz de tornar os homens símiles aos deuses e, como isso, testar a capacidade dos humanos de se manterem justos se tiverem esse poder ou, melhor dizendo, se não estiverem sendo vistos por outras pessoas. Pois esse é o real significado da invisibilidade, o que fazemos quando não somos vistos. Sendo o desafio que se faz, a partir da narrativa do anel da invisibilidade, é: quem se manteria justo mesmo invisível? A justiça é natural ao homem ou é apenas uma obrigação moral dada por um contrato legal entre os humanos, que qualquer um deixaria de cumprir quando não está sendo observado pelos outros humanos? A liberdade total é uma corrupção do desejo e tem relação direta com a pleonexía, que é a vontade de ter sempre mais. Se o ser humano se reduzir apenas ao desejo, então não será capaz de atos de justiça ou bondade em si mesmos, mas apenas se for coagido a agir conforme a lei estabelecida por um contrato. Gyges demonstra como o contrato pode ser deturpado pelo seu governante se a ele for permitido "agir como um deus" (Rep., 360c3). Dessa forma, o anel de Gyges é a metáfora do caminho do tirano.

A justiça só vale a pena se puder ser comprovada como natural, pois, do contrário, ela se torna uma obrigação que não será cumprida em caso de invisibilidade. Segundo Gláucon na República, o problema é que a liberdade total não permitiria aos homens construírem uma comunidade, pois cada um levaria em conta somente o que é seu e poderiam vir a prejudicar uns aos outros. O pleno gozo dos desejos seria a prova de que a injustiça é natural e deve ser freada com um contrato que institui a justiça. O anel de Gyges

\footnotetext{
3 PLATÃO (2006). República, 359b- 360b. Demais referências à "República" serão abreviadas por Rep. indicando em seguida a numeração.
} 
é o retorno do poder do desejo que ultrapassa até mesmo o contrato estabelecido socialmente. Dessa forma, o tirano se instala no governo. E por que o tirano? A tirania se constitui quando um homem detém todo o poder e faz dos cidadãos seus escravos. O tirano é o completamente injusto e controla a justiça, fazendo com que os governados cumpram a lei, enquanto ele mesmo não é obrigado a cumprir, pois é o próprio legislador e faz as leis em benefício próprio. Entendemos que o contrato proposto por Gláucon contribuirá para a sua tentativa de defender o governo injusto, ao atrelar ao completamente injusto a aparência da justiça,

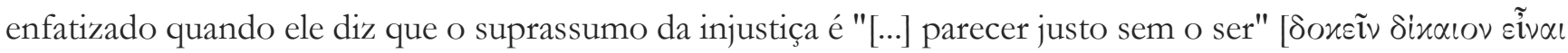

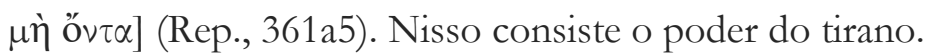

O mito do anel de Gyges tornará a aparecer nos Devaneios de um caminhante solitário de Jean-Jacques Rousseau. Os Devaneios é uma obra da maturidade de Rousseau, onde ele reflete sobre a sua vida com certa esperança amarga. Apesar de se manter convicto sobre uma bondade natural existente na humanidade, podemos perceber que o convívio em sociedade foi nocivo para Rousseau. Intrigas, desentendimentos, brigas e uma má interpretação de suas obras levou-o para o exílio. Ali, em contato novamente com a natureza e na solidão que lhe era peculiar, Rousseau se sente tocado para escrever os seus pensamentos durante suas caminhadas, pensamentos esses que são melancólicos sobre sua própria existência. Em sua sexta caminhada, Rousseau está a falar sobre a boa vontade que há nas ações que fazemos não por dever, mas por prazer. Ao fim da caminhada, ele resolve dissertar sobre o anel de Gyges:

Se tivesse permanecido livre, obscuro, isolado, como fora naturalmente feito, somente teria feito o bem: pois não tenho no coração o germe de nenhuma paixão prejudicial. Se tivesse sido invisível e todo poderoso como Deus, teria sido beneficente e bom como ele. É a força e a liberdade que fazem os excelentes homens. A fraqueza e a escravidão somente fizeram os maus. Se tivesse possuído o anel de Gyges ele me teria subtraído à dependência dos homens e os teria posto sob a minha. (ROUSSEAU, 1986, p. 87)

O anel de Gyges, como já dito anteriormente, é um artefato mágico que permite àquele que usá-lo tornar-se invisível e ser semelhante a Deus. Essa característica do anel faz com que ele seja um alvo forte de cobiça do ser humano. Na passagem acima, Rousseau reflete por hipótese o que aconteceria se ele tivesse tal anel. A princípio por ter uma boa índole, isto é, por ser naturalmente bom, ele iria procurar fazer somente o bem, pois agir livremente é também permitir a liberdade a todos os homens. No entanto, ter esse tipo de poder o faria sair da dependência dos homens para colocá-los na sua dependência. Isso o faz refletir sobre suas próprias atitudes tendo esse tipo de controle sobre os outros:

Perguntei-me, muitas vezes, ao fazer castelos no ar, que uso teria feito desse anel; pois é exatamente neste ponto que a tentação de enganar deve acompanhar o poder. Sendo dono de realizar meus desejos, podendo tudo sem poder ser enganado por ninguém, que teria podido desejar mais tarde? Uma única coisa: ver todos os corações contentes. (ROUSSEAU, 1986, p. 87)

Ter o governo dos outros para si não significa dizer que há um governo de si mesmo. Rousseau parece apontar para um problema da liberdade individual e do desejo que, ao tudo desejar, acaba aprisionando a si mesmo em seu desejo. Esse tipo de excesso da liberdade se torna impossível em sociedade, pois será através do ser social que surge o sujeito moral em Rousseau. Para apresentar o problema, Rousseau demonstra que existe uma deturpação em se achar que governar a todos sem se governar a si mesmo é um bem. Como nos diz Polanyi: 
[...] a sociedade livre só pode existir quando seus cidadãos têm espírito público, são desinteressados, dados a virtudes cívicas e estão dispostos a sacrificar tudo a serviço de seu país e de suas instituições livres. Em última instância, o indivíduo deve ser forçado a ser livre. (POLANYI, 2015, p. 62)

O que Polanyi parece indicar aqui é que essa força que constrange o indivíduo a ser livre é a mesma força que o obriga a ser justo. E isso só é possível se o indivíduo conseguir controlar as suas próprias paixões e agir de acordo com a justiça. O que só se torna possível se os humanos tiverem um senso moral e social em relação aos outros humanos. Dessa forma, o anel de Gyges representa um perigoso artefato que levaria ao aprisionamento do indivíduo em seus próprios desejos tirânicos.

Tudo bem considerado, creio que seria preferível jogar fora meu anel mágico, antes que me tivesse feito fazer alguma tolice. Se os homens se obstinarem em me ver completamente diferente do que sou e se minha vista excita sua injustiça, para que não me vejam é preciso fugir-lhes, mas não eclipsar-me entre eles.

[...] O resultado que posso extrair de todas essas reflexões é que não fui realmente feito para a sociedade civil onde tudo é opressão, obrigação, dever, e que meu natural independente me tornou sempre incapaz das sujeições necessárias a quem quiser viver com os homens. Enquanto ajo livremente sou bom e somente faço o bem; mas, logo que sinto o jugo, seja da fatalidade, seja dos homens, torno-me rebelde, ou melhor, insubmisso, então sou inexistente. (ROUSSEAU, 1986, p. 88)

Esse é o começo do enigma de Rousseau. Ele diz que jogaria o anel fora, pois o gosto pelo poder levaria inevitavelmente ao seu aprisionamento. Como somos apenas humanos, mesmo que quiséssemos usar o anel para o bem, acabaríamos caídos na tentação pelo poder e nos tornaríamos, ao invés de senhores, escravos do anel. Por isso o anel é perigoso e deve ser jogado fora. Dessa forma, Rousseau nos apresenta uma considerável lição da justiça que vem da força interior do indivíduo e não de uma obrigação de uma justiça contratual apenas, o que indica, em Rousseau, uma justiça interior que permite ao indivíduo a manifestação do governo de si do cidadão em sociedade, pois, como diz o próprio Rousseau: "nunca acreditei que a liberdade do homem consistisse em fazer o que quer mas sim em fazer o que não quer" (1986, p. 88).

A identificação de Rousseau com uma liberdade negativa para se fazer o bem, pode ser entendida como o governo de si mesmo, isto é, agir de maneira justa e manter as suas ações dentro do limite possível para não atravessar o limite do outro. No momento em que não mais vemos o outro, em que estamos presos em nosso próprio solipsismo do cogito virtual, tudo o mais é permitido. Perdemos a noção do nosso próprio limite e acabamos invadindo o limite alheio, pois o outro deixa de ser concreto para mim e posso agir como me convém. Somente com uma retomada do real se pode reconquistar a noção do limite entre o eu e o outro.

\section{A máquina utópica: a reconquista do real}

Por fim, chegamos à utopia. Mas em que consiste tal mecanismo? Em um mundo humano dominado pelos meios virtuais e com uma concepção fragmentada do real, qual mundo possível podemos construir? Segundo o parecer de Bruno Latour,

[a] primeira lição do coronavírus é também a mais espantosa. De fato, ficou provado que é possível, em questão de semanas, suspender, em todo o mundo e ao mesmo tempo, um sistema econômico que até agora nos diziam ser impossível desacelerar ou redirecionar. A todos os argumentos apresentados pelos ecologistas sobre a necessidade de alterarmos nosso modo de vida, sempre se opunha o argumento da força irreversível do "trem do progresso", que nada era capaz de tirar dos trilhos, "em virtude", dizia-se, 
da "globalização". Ora, é justamente seu caráter globalizado que torna tão frágil o famoso desenvolvimento, o qual, ao contrário, pode sim ser desacelerado e finalmente parado. (LATOUR, 2020)

O incessante progresso que antes era a ordem comum ouvida nas economias de mercado, agora foi abandonado perante a crise causada pelo vírus. O que se levou anos articulando com o objetivo de acabar com o capitalismo voraz que nos oprime diariamente, se tornou parte de nossa realidade pandêmica. Não é certo ainda que esse mundo desacelerado e menos econômico seja o futuro que nos espera. É mais provável que não seja e, por isso mesmo, devemos lutar pela construção de uma utopia global. Utopia é a junção de duas palavras gregas que significam uma espécie de "não-lugar", algo que muitas vezes pode ser tomado como ideal, fora do lugar e não alcançável ${ }^{4}$. Ou que só pode ser atingido em um futuro não-temporal. Ao contrário da obra de Thomas More (2018), em que Utopia é apenas uma ilha distante, entendemos que a utopia que almejamos, por mais difícil que seja, não deixa de ser um tipo de mundo possível. Um mundo possível pós-viral, seja ele qual for, perpassa pela reconquista do real e uma ressignificação do próprio mundo. E isso pode ser a construção de uma utopia. O processo agora é de pensar como será constituída essa utopia e de que forma ela pode se tornar real.

Em seu livro sobre a pandemia, Zizek (2020a) permite-se pensar a possibilidade de um comunismo a partir da crise global. A solidariedade seria a chave para a formação desse novo comunismo a surgir. É uma possibilidade, mas não a única. Gostaríamos aqui de pensar algumas perspectivas possíveis para que isso possa se realizar. Há diferentes capitalismos (liberalismo, neoliberalismo, capitalismo de mercado), diversos socialismos (comunismo e anarquismo inclusos). Há a tentativa de unir liberalismo e socialismo (social democracia). Vamos fazer uma análise mais acurada do que poderia ser a proposta marxiana para o comunismo.

Primeiramente, Marx não teorizou muito sobre o comunismo, justamente por se ater ao que existe. Mesmo já teorizado por outros pensadores, o comunismo não existia na sua época, portanto, ainda precisava ser inventado. O Manifesto Comunista longe está de ser uma obra teórica como o Capital, por exemplo. No entanto, entendemos que nem Marx e nem Engels hesitariam em escrever o que escreveram sobre o comunismo, mesmo sabendo o que poderia resultar daí, simplesmente por não ser o mesmo o modelo implantado nos Estados comunistas e aquilo que Marx e Engels defendiam em seus livros. Para ilustrar o que queremos dizer aqui, colocamos uma citação de Marx e Engels do Manifesto Comunista: "os comunistas trabalham para a união e pelo entendimento dos partidos democráticos de todos os países" (2005, p. 69). Decorrente disso, podemos dizer que o comunismo defendido por Marx e Engels não é antidemocrático e muito menos totalitário. Aproveito o termo totalitário para esclarecer que o tipo de acusação que se faz a Marx de ser um modelo teórico para o totalitarismo tem por princípio a obra de Karl Popper, A sociedade aberta e seus inimigos. No volume 1(2012), Popper ataca Platão fazendo um paralelo com o fascismo. No volume 2 (2013), Popper ataca Marx fazendo um paralelo como o comunismo da URSS.

Entretanto, entendemos que a interpretação totalitária do comunismo é equivocada. O comunismo tem alguns princípios básicos para ser implementado, sendo o primeiro deles a socialização dos meios de produção nas mãos dos trabalhadores (e não do Estado como faz a China, por exemplo). Depois é preciso acabar com a exploração do trabalho (mais-valor) e, por fim, acabar com a sociedade de classes. Quanto à "ditadura do proletariado", que tantos acusam Marx, o termo, de fato, aparece na Crítica ao programa de Gotha (MARX, 2012) e faz referência ao período de transição entre capitalismo e comunismo. Portanto, a ditadura

${ }^{4}$ Оuтопі́ = "ou” (não) + "то́поc" (lugar). 
do proletariado não é o comunismo defendido por Marx, mas uma fase anterior ao comunismo. Segundo Marx, o proletariado não deve se tornar a classe dominante no lugar da burguesia, mas, ao tomar o poder, o objetivo é instaurar a sociedade sem classes. Isso é o comunismo esperado: sociedade sem classes. E Marx defendia isso.

Peguemos, por exemplo, a grande obra de Marx, O Capital. Essa obra é, a nosso ver, a maior análise sobre o capitalismo já feita, pois é onde Marx desvela toda a artimanha burguesa para se manter como a classe dominante no mundo. Será através desta obra que Marx irá mostrar como o trabalhador é reduzido a uma mera mercadoria como qualquer outra, tendo a sua mão de obra explorada, o que leva a sua total destruição como ser humano que é.

Em nossa concepção, a utopia do porvir será construída através de um novo comunismo. Não o velho comunismo totalitário e estatal, mas um comunismo que tenha como lemas a autogestão dos indivíduos, solidariedade e autoajuda. Pode parecer estranho falar de um comunismo utópico aqui, já que no passado foi tão defendido justamente um comunismo científico. Mas creio que conseguimos nos justificar no uso da palavra utopia para indicar algo que ainda não existe e que precisa ser construído. Não estamos usando velhos modelos e nem algum que exista na realidade atual. Estamos a tratar de algo que precisa ainda ser inventado. Para isso, o capitalismo neoliberal precisa ruir e acabar definitivamente. Uma reconfiguração da sociedade precisa surgir como ideia, primeiramente, para que haja depois o combate contra a ideologia burguesa que domina o status quo. Sem isso, não há como romper com nada do que está em voga, pois aquilo que foi gravado em ferro na memória das pessoas, dificilmente se apaga com o sofrimento de uma crise. O capitalismo já atravessou diversas crises, sendo algumas delas bem catastróficas, mas sempre acaba por se recuperar e seguir em frente cada vez mais voraz. Somente uma ruptura feita em sua base ideológica poderia acabar com as consequências nefastas desse modo de produção. É preciso lidar com a pluralidade existente na classe trabalhadora que não a faz se reconhecer como una. Essa fragmentação se dá por um processo de desarticulação entre os membros de classe que não conseguem se situar como uma classe. Um problema que perpassa o sistema ideológico capitalista que se sobrepõe a todo processo exploratório. De maneira que o trabalhador não se reconhece como um explorado pelo sistema e acaba por defender o mesmo sistema que o explora, seguindo a mesma linha de raciocínio burguês. Por esse motivo, o combate à ideologia se faz essencial ao processo de construção utópico do novo comunismo.

Isso perpassa, de certa maneira, à reconfiguração do humanismo, não apenas com a problemática clássica humana, mas envolvendo a problemática sobre o papel da natureza e da tecnologia, assim como a maneira como nós humanos devemos lidar com essas duas. O modelo exploratório da natureza chegou ao seu auge e não há mais como comportar tal modelo no mundo atual. No entanto, as grandes empresas de tecnologia como Google, Microsoft e Amazon já estão pensando em um modelo pós-humanista, feito para manter o isolamento dos mais ricos através do suporte tecnológico aprimorado e aplicativos de entregas, como o Ifood, só para citar o mais famoso. Enquanto isso, a maioria das pessoas viveria subempregada e exercendo a maior parte das atividades que sustentariam o status quo da classe dominante (KLEIN, 2020; ZIZEK, 2020b).

É preciso um novo olhar sobre a natureza que permita ao homem a convivência harmônica com esta. A formação de um pós-humanismo surgirá a partir da relação humano, natureza e máquina. Mas que mundo podemos ter a partir disso é ainda uma construção em aberto. Nossa proposta de retomar um comunismo utópico perpassa por uma reinterpretação do próprio comunismo, utilizando-se de todo cabedal que já possuímos em teoria para a formulação de uma nova práxis. Isso envolve a reformulação da categoria "trabalho" tão cara a Marx como formação e transformação humana. Acabar com o trabalho como sendo a 
mera exploração da força do trabalhador para formação de mais-valor e lucro para os empresários, estimulado e perpetuado pelo sistema capitalista, para a construção de um trabalho como categoria existencial do humano inerente ao seu desenvolvimento. O comunismo não pode mais estar vinculado unicamente às veias totalitárias da União Soviética e demais países ditos comunistas, mas é preciso repensar a sua execução. É por isso que retomamos o termo "utopia": para que façamos uma ressignificação do comunismo como uma via que englobe toda humanidade em um modo de produção mais coerente com aquilo que nos faz humanos. Quando falamos em pós-humanismo é no sentido de repensar o humano que somos e as possibilidade que irão advir a partir da nossa escolha de como vamos lidar com a tecnologia e com a natureza. Como o futuro ainda é incerto e sua escrita em aberto, será a escolha do caminho que iremos traçar que fará toda a diferença para nos dizer que mundo teremos no futuro. Por isso que precisamos romper com o mecanicismo, que toma a natureza como mero objeto das determinações humanas, para entender que a natureza tem o seu próprio modo de agir e não nos cabe determiná-la. Que tipo de mundo podemos construir após a pandemia só cabe às nossas próprias interações para romper com antigos modelos e construir novos no lugar.

\section{Conclusão}

Neste trabalho, assumimos duas tarefas principais. A primeira foi uma análise descritiva e crítica do momento atual pelo qual passamos através da analogia com a máquina e suas vertentes humana, econômicopolítica, ética e utópica. O método que adotamos foi na necessidade de se dialogar com a filosofia do mecanismo, de modo que nos permitisse refletir a automatização do mundo em que vivemos e o mecanicismo que guia a vida das pessoas sem que elas se deem conta disso.

A segunda tarefa foi propositiva e se preocupou em pensar a questão sobre qual mundo possível deveríamos desejar ao fim da pandemia viral. Nesse sentido, a partir das análises feitas ao longo do artigo, se propôs um novo comunismo como resposta pós-viral para uma readequação global. Para isso, se faz necessário repensar o humanismo, entendendo a sua dimensão natural e o fim do modelo exploratório, que não mais se adequa ao mundo atual. Um novo olhar sobre a natureza se faz necessário de maneira que se possa conciliar o humano em todas as suas novas dimensões junto à natureza e à tecnologia.

Feito isso, podemos concluir este trabalho não como algo estritamente determinado, mas como uma obra aberta ainda a ser explorada e redescoberta, buscando significado para as relações sociais existentes no mundo e suas possibilidades de reconfiguração.

\section{Referências}

ACCOMINOTTI et al. Globalisation and financial contagion: A history. Vox, 2020. Disponível em: https://voxeu.org/article/globalisation-and-financial-contagion. Acesso em: 11/04/2020.

ACOSTA, A. Quem está lucrando com o Coronavírus? Duplo Expresso, 2020. Disponível em: https://duploexpresso.com/?p=112061. Acesso em: 12/04/2020.

ADAM, D. Special report: The simulations driving the world's response to COVID-19. Nature, 2020. Disponível em: https://www.nature.com/articles/d41586-020-01003-6. Acesso em: 16/04/ 2020.

AHMED, N. Will Covid-19 end the age of Big Oil? Le Monde Diplomatique, 24/04/2020. Disponível em: https://mondediplo.com/outsidein/covid-19-oil. Acesso em: 27/04/2020. 
AMADEO, P. (ed.). Sopa de Wuhan. [S.I]: ASPO, 2020.

ANG, Y. Y. When COVID-19 meets centralized, personalized power. Nature, 2020. Disponível em: https://www.nature.com/articles/s41562-020-0872-3. Acesso em: 16/04/2020.

APPELBAUM, E.; PARK, A.; BATT, R. How Private Equity Firms Will Profit From COVID-19. The American Prospect, 07/05/2020. Disponível em: https://prospect.org/coronavirus/private-equity-firmsprofit-covid-19-j-crew/. Acesso em: 16/05/2020.

ARBIX, G. Ciência e tecnologia salvam vidas. Mas ainda falta reconhecimento. Nexo Jornal, 2020. Disponível em: https://www.nexojornal.com.br/ensaio/debate/2020/Ci\%C3\%AAncia-e-tecnologiasalvam-vidas.-Mas-ainda-falta-reconhecimento. Acesso em: 14/04/2020.

BAELE, S. On the Securitization of COVID-19. Pandemipolitics, 2020. Disponível em: https://pandemipolitics.net/security/baele/. Acesso em: 14/04/2020.

BATTISTI, C. A. A Natureza do Mecanismo Cartesiano. PERI, v. 02, n. 02, p. 28-46, 2010.

BENJAMIN, C. (Org.). Estudos sobre Rousseau. Rio de Janeiro: Contraponto, 2015.

BENJAMIN, M. Engines of life. Aeon, 2020. Disponível em: https://aeon.co/essays/the-future-isnano-and-it-will-revolutionise-medical-science. Acesso em: 16/04/2020.

BISCOP, S. Coronavirus and Power: The Impact on International Politics. Security Policy Brief, 126, p. 1-4, 2020.

BRACERO, F. Geolocalización contra el coronavirus. La Vanguarda, 2020. Disponível em: https://www.lavanguardia.com/tecnologia/20200410/48402692952/geolocalizacion-coronavirus-datos-app-medidas-boe.html. Acesso em: 11/04/2020.

BREÑA, C. M. Pandemias do passado, velhas quarentenas e novos ensinamentos. El País, 2020. Disponível em: https://brasil.elpais.com/sociedade/2020-04-09/pandemias-do-passado-velhasquarentenas-e-novos-ensinamentos.html?ssm=FB_BR_CM. Acesso em: 16/04/2020.

BROOKS, C. Reopening Our Economy Right Now Will Result in Mass Death. Jacobin, 04/05/2020. Disponivel em: https://jacobinmag.com/2020/05/coronavirus-pandemic-reopen-economy-workers-crisis?. Acesso em: 16/05/2020.

BRUM, E. O futuro pós-coronavírus já está em disputa. El País, 2020. Disponível em: https://brasil.elpais.com/opiniao/2020-04-08/o-futuro-pos-coronavirus-ja-esta-em-disputa.html. Acesso em: 16/04/2020.

BUITER, W. H. Pandemic Socialism. Project Syndicate, 2020. Disponível em: https://www.projectsyndicate.org/commentary/covid19-pandemic-requires-socialism-by-willem-h-buiter-1-2020-04. Acesso em: 16/04/2020.

CABRERA, Y. Coronavirus Is Not Just a Health Crisis-It's an Environmental Justice Crisis. Mother Jones, 25/04/2020.

CAETANO, E. Governos estão a aproveitar Covid-19 para avançar na "arquitetura da opressão", alerta Edward Snowden. Observador, 2020. Disponível em: https://observador.pt/2020/04/12/ governos-estao-a-aproveitar-covid-19-para-avancar-na-arquitetura-da-opressao-alerta-edward-snowden/. Acesso em: 14/04/2020.

CAMUS, A. Estado de Sítio. Tradução de Alcione Araújo e Pedro Hussak. Rio de Janeiro: Civilização Brasileira, 2002.

CAYLEY, D. Questions about the current pandemic from the point of view of Ivan Illich. Quodlibet, 
2020. Disponível em: https://www.quodlibet.it/david-cayley-questions-about-the-current-pandemic-from-the-point. Acesso em: 14/04/2020.

CHIN, L. Planetary Hysteria: Manufactured COVID-19 “Health Crisis” Pushes Humanity, Global Society to Total Shutdown. Global Research, 2020. Disponivel em: https://www.globalresearch.ca/planetary-hysteria-manufactured-covid-19-health-crisis-pushes-humanity-global-society-total-shutdown/5707607. Acesso em: 12/04/2020.

CHOMSKY, N. Noam Chomsky on Trump's Disastrous Coronavirus Response, Bernie Sanders \& What Gives Him Hope. Entrevista concedida a Amy Goodman. Democracy Now, 2020. Disponível em: https://www.democracynow.org/2020/4/10/noam_chomsky_trump_us_coronavirus_response. Acesso em: 16/04/2020.

CHOMSKY, N. Chomsky: "coronavírus é algo sério o suficiente, mas há algo mais terrível se aproximando". Entrevista concedida a Srećko Horvat. Diálogos do Sul, 2020. Disponível em: https://dialogosdosul.operamundi.uol.com.br/direitos-humanos/63998/chomsky-coronavirus-e-algo-serio-osuficiente-mas-ha-algo-mais-terrivel-se-aproximando. Acesso em: 16/04/2020.

CLOUET, H.; QUIJOUX, M. The Pandemic Response Shows How Workers Defend the Interests of All Humanity. Jacobin, 07/05/2020. Disponível em: https://jacobinmag.com/2020/05/coronaviruscovid-france-factory-workers-labor-ppe-masks. Acesso em: 16/05/2020.

COHEN, P. Straggling in a Good Economy, and Now Struggling in a Crisis. The New York Times, 16/04/2020. Disponível em: https://www.nytimes.com/2020/04/16/business/economy/coronavirus-economy.html. Acesso em: 22/04/2020.

DARDOT, P.; LAVAL, C. A nova razão do mundo. Ensaio sobre a sociedade neoliberal. São Paulo: Boitempo, 2016. (Ebook)

DARWIN, C. A origem das espécies. São Paulo: Ubu Editora, 2018. (Ebook)

DAVIS, M. et al. Coronavírus e a luta de classes. [S.I.]: Terra sem Amos, 2020.

DAVIS, M. Mike Davis: Reopening the Economy Will Send Us to Hell. Jacobin, 27/04/2020. Disponível em: https://jacobinmag.com/2020/04/mike-davis-economy-coronavirus-crisis-trump. Acesso em: 01/05/2020.

DAY, M. Billionaires Are the Pandemic's Villains, Not Its Heroes. Jacobin, 27/04/2020. Disponível em: https://jacobinmag.com/2020/04/billionaires-coronvirus-pandemic-profiteers-taxes. Acesso em: 01/05/2020.

DESCARTES, R. Meditações. São Paulo: Abril Cultural, 1979. (Os Pensadores)

DESCARTES, R. Discurso do Método \& Ensaios. São Paulo: Editora Unesp, 2018.

DRYZEK, J. S. et al. The crisis of democracy and the science of deliberation. Science, v. 363, p. 1144-1146, 2019.

EAVES, E. Hot zone in the heartland? Bulletin of the Atomic Scientists, 2020. Disponivel em: https://thebulletin.org/2020/03/hot-zone-in-the-heartland/. Acesso em: 16/04/2020.

ESCOBAR, P. Total system failure will give rise to new economy. Asia Times, 09/04/2020. Disponível em: https://asiatimes.com/2020/04/total-system-failure-will-give-rise-to-new-economy/. Acesso em: 17/04/2020.

ESCOBAR, P. Confucius is winning the Covid-19 war. Asia Times, 13/04/2020. Disponível em: https://asiatimes.com/2020/04/confucius-is-winning-the-covid-19-war/. Acesso em: 17/04/ 2020. 
ESCOBAR, P. The city in a time of plague. Asia Times, 17/04/2020. Disponível em: https://asiatimes.com/2020/04/the-city-in-a-time-of-plague/. Acesso em: 27/04/2020.

ESCOBAR, P. The unbearable lightness of China. Asia Times, 23/04/2020. Disponível em: https://asiatimes.com/2020/04/the-unbearable-lightness-of-china/. Acesso em: 27/04/2020.

ESCOBAR, P. What Did U.S. Intel Really Know About the 'Chinese' Virus? Strategic Culture Foundation, 21/04/2020. Disponível em: https://www.strategic-culture.org/news/2020/04/21/whatdid-us-intel-really-know-about-chinese-virus/. Acesso em: 29/04/2020.

FERNANDES, L. V. EUA. Bilionários enriquecem durante pandemia. Bezos e Musk entre os que mais ganharam. Observador, 23/04/2020. Disponível em: https://observador.pt/2020/04/23/_trashed-864/. Acesso em: 24/04/2020.

FILDES, N.; ESPINOZA, J. Tracking coronavirus: big data and the challenge to privacy. Financial Times, 2020. Disponível em: https://www.ft.com/content/7cfad020-78c4-11ea-9840-1b8019d 9a987. Acesso em: 11/04/2020.

FORSTER, E. M. The Machine stops. Tradução de Celso R. Braida. (n.t.) Revista Literária em Tradução, v. 01, n. 02, p. 217-279, 2011.

FREIRE, V. T. Número de casos de Covid-19 é sete vezes maior, estima primeiro grande estudo no Brasil. Folha de SP, 2020. Disponivel em: https://www1.folha.uol.com.br/equilibrioesaude/2020/04/numero-de-casos-de-covid-19-e-sete-vezes-maior-estima-primeiro-grande-estudo-no-brasil.shtml?utm_source=whatsapp\&utm_medium=social\&utm_campaign=compwa. Acesso em: 15/04/2020.

G1. Brasil tem 727 mortes por coronavírus em 24 horas, mostra consórcio de veículos de imprensa; são 58.385 no total. G1, 29/06/2020. Disponível em: https://g1.globo.com/bemestar/coronavirus/noticia/2020/06/29/casos-e-mortes-por-coronavirus-no-brasil-29-de-junho-segundo-consorcio-de-veiculos-de-imprensa.ghtml. Acesso em: 29/06/2020.

GRIFFIN, D.; DENHOLM, J. This isn't the first global pandemic, and it won't be the last. Here's what we've learned from 4 others throughout history. The Conversation, 2020. Disponível em: https://theconversation.com/this-isnt-the-first-global-pandemic-and-it-wont-be-the-last-hereswhat-weve-learned-from-4-others-throughout-history-136231. Acesso em: 20/04/2020.

'GRIPEZINHA': leia a íntegra do pronunciamento de Bolsonaro sobre covid-19. UOL, 24/03/2020. Disponível em: https://noticias.uol.com.br/politica/ultimas-noticias/2020/03/24/leia-o-pronunciamento-do-presidente-jair-bolsonaro-na-integra.htm. Acesso em: 20/04/2020.

GUEST AUTHORS. The Body Politics of Covid-19. The Disorder of Things, 2020. Disponível em: https://thedisorderofthings.com/2020/04/06/the-body-politics-of-covid-19/. Acesso em: 16/04/ 2020.

GURGEL, V.; MOTA, F.; COSTA, A. Necropolítica neoliberal e tanatologia jurídico-trabalhista. Justificando, 07/05/2020. Disponível em: http://www.justificando.com/2020/05/07/necropolitica-neoliberal-e-tanatologia-juridico-trabalhista/. Acesso em: 16/05/2020.

HARVEY, D. Para entender o Capital Livro 1. São Paulo: Boitempo, 2013.

HARVEY, D. Para entender o Capital Livro 2 e 3. São Paulo: Boitempo, 2014.

HARVEY, D. A política anticapitalista na época da COVID-19. Instituto Humanitas Unisinos, 26/03/2020. Disponível em: http://www.ihu.unisinos.br/78-noticias/597468-a-politica-anticapitalista-na-epoca-da-covid-19-artigo-de-david-harvey. Acesso em: 29/04/2020. 
HARWELL, D. Companies' use of thermal cameras to speed return to work sparks worries about civil liberties. The Washington Post, 27/04/2020. Disponivel em: https://www.washingtonpost.com/technology/2020/04/27/companies-use-thermal-cameras-speed-return-work-sparksworries-about-civil-liberties/. Acesso em: 27/04/2020.

HEDIDAR, W. Designing and Consuming Post-Pandemic Futures. The Metric, 2020. Disponível em: https://www.themetric.org/articles/designing-and-consuming-post-pandemic-futu-

res?fbclid=IwAR2uupfwy3YV_dtbX4va16eeYRH5mQigOJHOQyAJ3MKUMWeqzlodSpfttss. Acesso em: 14/04/2020.

HEER, J. Thanks to Covid-19, Neoliberal Globalization Is Unraveling. The Nation, 17/04/2020. Disponível em: https://www.thenation.com/article/world/globalization-unravelling-internationalismcoronavirus/. Acesso em 26/04/20.

HOBBES, T. Leviatã. Organizado por Richard Tuck. Tradução de João Paulo Monteiro e Maria Beatriz Nizza da Silva. São Paulo: Martins Fontes, 2008.

HOBBES, T. Os Elementos da Lei Natural e Política. Tradução de Bruno Simões. São Paulo: Martins Fontes, 2010.

HORVAT, S. Mais contagioso é o medo. El País, 2020. Disponível em: https://brasil.elpais.com/internacional/2020-02-16/mais-contagioso-e-o-medo.html. Acesso em: 16/04/2020.

HU, Z. A New Age of Destructive Austerity After the Coronavirus. The New Republic, 23/04/2020. Disponível em: https://newrepublic.com/article/157417/new-age-destructive-austerity-coronavirus. Acesso em: 02/05/2020.

IYER, L. living in the end times. Entrevista concedida a Markku Nivalainen. 3:AM Magazine, 2020. Disponível em: https://www.3ammagazine.com/3am/living-in-the-end-times/. Acesso em: 11/04/ 2020.

KEANE, J. Democracy and the Great Pestilence. Eurozine, 17/04/2020. Disponível em: https://www.eurozine.com/democracy-and-the-great-pestilence/. Acesso em: 26/04/2020.

KEYNES, J. M. O fim do 'laissez-faire'. In: SZMRECSÁNYI, T. (org.) Keynes (Economia). Tradução Miriam Moreira Leite. São Paulo: Ática, 1984, p. 106-126.

KHAMSI, R. If a coronavirus vaccine arrives, can the world make enough? Nature, 2020. Disponível em: https://www.nature.com/articles/d41586-020-01063-8. Acesso em: 16/04/2020.

KISSLER, S. M. et al. Projecting the transmission dynamics of SARS-CoV-2 through the postpandemic period. Science, 2020. Disponivel em: https://science.sciencemag.org/content/early/2020/ 04/14/science.abb5793. Acesso em: 14/04/2020.

KLEIN, N. Screen New Deal. The Intercept, 08/05/2020. Disponivel em: https://theintercept.com/2020/05/08/andrew-cuomo-eric-schmidt-coronavirus-tech-shock-doctrine/. Acesso em: 24/05/2020.

LACOMBE, C.; LOISEAU, V. Smartphone et covid-19 : allons-nous tous finir addicts? La Tribune, 07/05/2020. Disponível em: https://acteursdeleconomie.latribune.fr/debats/opinion/2020-0507/smartphone-et-covid-19-allons-nous-tous-finir-addicts-847220.html. Acesso em: 13/05/2020.

LAMBERT, R.; RIMBERT, P. Até o próximo fim do mundo. Le Monde Diplomatique Brasil, 2020. Disponível em: https://diplomatique.org.br/ate-o-proximo-fim-do-mundo/. Acesso em: 16/04/ 2020.

LAPAVITSAS, C. Esta crise expôs o declínio do neoliberalismo e não vai destruí-lo sem luta de classe. 
Jacobin Brasil, 09/04/2020. Disponível em: https://jacobin.com.br/2020/04/esta-crise-expos-0declinio-do-neoliberalismo-e-nao-vai-destrui-lo-sem-luta-de-classe/. Acesso em: 01/05/2020.

LATOUR, B. Imaginar gestos que barrem o retorno da produção pré-crise. $n$-1 edições, 29/03/2020. Disponível em: https://n-1edicoes.org/008-1. Acesso em: 16/04/2020.

LOPES, R. J. Distanciamento social intermitente pode ser necessário até 2022 se não houver vacina, diz estudo na Science. Folha de SP, 2020. Disponível em: https://www1.foIha.uol.com.br/equilibrioesaude/2020/04/distanciamento-social-intermitente-pode-ser-necessario-ate-2022-diz-estudo-na-science.shtml. Acesso em: 14/04/2020.

MAGALHÃES, J. C.; COULDRY, N. Tech Giants Are Using This Crisis to Colonize the Welfare System. Jacobin, 27/04/2020. Disponível em: https://jacobinmag.com/2020/04/tech-giants-coronaviruspandemic-welfare-surveillance. Acesso em: 01/05/2020.

MALTHUS, T. Ensaio sobre a população. [S.I.]: Lebooks Editora, 2017. (Ebook)

MARICONDA, P. R. Introdução: Ciência e Técnica em Discurso do Método \& Ensaios de Descartes. In: DESCARTES, R. Discurso do Método \& Ensaios. São Paulo: Editora Unesp, 2018, p. 11-60.

MARX, K. Manuscritos Econômico-Filosóficos. São Paulo: Boitempo, 2004.

MARX, K.; ENGELS, F. Manifesto Comunista. São Paulo: Boitempo, 2005.

MARX, K. Crítica do Programa de Gotha. São Paulo: Boitempo, 2012.

MARX, K. O Capital, Crítica da Economia Política, livro I. São Paulo, Boitempo, 2013.

MARX, K. O Capital, Crítica da Economia Política, livro II. São Paulo, Boitempo, 2015.

MARX, K. O Capital, Crítica da Economia Política, livro III. São Paulo, Boitempo, 2017.

MBEMBE, A. The Universal Right to Breathe. Critical Inquiry, 2020. Disponível em: https://critinq.wordpress.com/2020/04/13/the-universal-right-to-breathe/. Acesso em: 14/04/2020.

MBEMBE, A. Necropolítica. Biopoder, soberania, estado de exceção, política da morte. São Paulo: $\mathrm{n}$-1 edições, 2018.

MENEZES, L. M. B. R. O problema da filosofia política. Investigação Filosófica, v. 10, n. 1, p. 141$152,2019$.

MENEZES, L. M. B. R. A aporía democrática: o caminho de Prometeu. Investigação Filosófica, v. 11, n. 1, p. 85-92, 2020.

MOODY, K. How “Just-in-Time” Capitalism Spread COVID-19. Spectre, 2020. Disponível em: https://spectrejournal.com/how-just-in-time-capitalism-spread-covid-19/. Acesso em: 14/04/ 2020.

MOORE, S. COVID-19 and the future of open access. Samuel Moore, 2020. Disponível em: https://www.samuelmoore.org/2020/04/07/covid-19-and-the-future-of-open-access/. Acesso em: 14/04/2020.

MORE, T. Utopia. Tradução de Denise Bottmann. São Paulo: Peguin; Companhia das Letras, 2018. MOREIRA, R. S. Neoliberalismos, ciência e saúde coletiva. Carta Maior, 2020. Disponível em: https://www.cartamaior.com.br/?\%2FEditoria\%2FSaude\%2FNeoliberalismos-ciencia-e-saude-coletiva\%2F43\%2F47114. Acesso em: 11/04/2020.

MOURA, M. Tecnologia e as serras: teletrabalho na pós-pandemia. Revista Piauí, 07/05/2020. Disponível em: https://piaui.folha.uol.com.br/tecnologia-e-as-serras-teletrabalho-na-pos-pandemia/. 
Acesso em: 13/05/2020.

NELSON, A. Society after Pandemic. Items, 23/04/2020. Disponível em: https://items.ssrc.org/covid-19-and-the-social-sciences/society-after-pandemic/. Acesso em: 03/05/2020.

O'CONNELL, P. The Morals of the Market and the Moral of the Story. Legal Form, 2020. Disponivel em: https://legalform.blog/2020/03/12/the-morals-of-the-market-and-the-moral-of-the-story-pa ul-oconnell/. Acesso em: 14/04/2020.

O'CONNOR, C.; WEATHERAL, J. O. Why False Claims About COVID-19 Refuse to Die. Nautilus, 2020. Disponível em: http://nautil.us/issue/84/outbreak/why-false-claims-about-covid_19-refuse-todie?mc_cid=bdObdfdaf1\&mc_eid=5358a5d12f. Acesso em: 20/04/2020.

OURO fecha em alta, com busca por segurança no mercado ante queda do petróleo. Isto é, 20/04/2020. Disponível em: https://istoe.com.br/ouro-fecha-em-alta-com-busca-por-segurancano-mercado-ante-queda-do-petroleo/. Acesso em: 22/04/2020.

OZKIRIMLI, U. Coronationalism? Open Democracy, 2020. Disponível em: https://www.opendemocracy.net/en/can-europe-make-it/coronationalism/. Acesso em: 14/04/2020.

ÖZSU, U. Neoliberalism, Human Rights, and the Socialist Imperative. Legal Form, 2020. Disponível em: https://legalform.blog/2020/03/21/neoliberalism-human-rights-and-the-socialist-imperativeumut-ozsu/. Acesso em: 14/04/2020.

PETTY, S. Neoliberal Healthcare Fails the COVID Test. New Politics, 07/05/2020. Disponível em: https://newpol.org/neoliberal-healthcare-fails-the-covid-test/. Acesso em: 16/05/2020.

PICKARD, V. Coronavirus Is Hammering the News Industry. Here's How to Save It. Jacobin, 20/04/2020. Disponível em: https://jacobinmag.com/2020/04/coronavirus-news-industrynewspapers-journalists-layoffs? Acesso em: 17/05/2020.

PIRONE, M. Politiche della pandemia. Neoliberismo, riproduzione sociale e tecnopolitica. EuroNomade, 2020. Disponível em: http://www.euronomade.info/?p=13257. Acesso em: 11/04/2020.

PLATÃO. A República. Tradução e organização de J. Guinsburg. São Paulo: Perspectiva, 2006.

POLANYI, K. É possível uma sociedade livre? In: BENJAMIN, C. (Org.). Estudos sobre Rousseau. Rio de Janeiro: Contraponto, 2015, p. 53-65.

POPPER, K. A Sociedade Aberta e os Seus Inimigos: o Sortilégio de Platão. Lisboa: Edições 70, 2012.

POPPER, K. A Sociedade Aberta e os Seus Inimigos: Hegel e Marx. Lisboa: Edições 70, 2013.

POWELL, A. An awakening over data privacy. The Harvard Gazette, 2020. Disponível em: https://news.harvard.edu/gazette/story/2020/02/surveillance-capitalism-author-sees-data-privacy-awakening/. Acesso em: 13/04/2020.

PUTZ, C. Human Rights Beyond the Time of Coronavirus. The Diplomat, 24/04/2020. Disponível em: https://thediplomat.com/2020/04/human-rights-beyond-the-time-of-coronavirus/. Acesso em: 22/05/2020.

REZENDE, J. M. As grandes epidemias da história. In: REZENDE, J. M. À sombra do plátano: crônicas de história da medicina. São Paulo: Editora Unifesp, 2009, p. 73-82. [online].

ROBERTS, S. L. Covid-19: the controversial role of big tech in digital surveillance. LSE Business Review, 2020. Disponível em: https://blogs.Ise.ac.uk/businessreview/2020/04/25/covid-19-thecontroversial-role-of-big-tech-in-digital-surveillance/. Acesso em: 28/04/2020. 
ROUSSEAU, J.-J. Do Contrato Social. Tradução de Lourdes Santos Machado. São Paulo: Abril Cultural, 1978. (Coleção Os Pensadores)

ROUSSEAU, J.-J. Discurso sobre a Origem e os Fundamentos da Desigualdade entre os Homens. Tradução de Maria Ermantina Galvão. São Paulo: Martins Fontes, 2002.

ROUSSEAU, J.-J. Os devaneios do caminhante solitário. Tradução de Fúlvia Maria Luiza Moretto. Brasília: Editora Universidade de Brasília; HUCITEC, 1986.

SABADELL, D. F. El confinamiento 'saludable': ¿un privilegio de clase? El Salto, 2020. Disponível em: https://www.elsaltodiario.com/coronavirus/confinamiento-saludable-privilegio-clase. Acesso em: 16/04/2020.

SAFATLE, V. Preparar-se para a Guerra. El País, 20/04/2020. Disponível em: https://brasil.elpais.com/opiniao/2020-04-20/preparar-se-para-a-guerra.html. Acesso em: 22/04/2020.

SANDERSON, D. Coronavirus an 'existential threat' to Africa and her crowded slums. The Conversation, 2020. Disponível em: https://theconversation.com/coronavirus-an-existential-threat-to-africaand-her-crowded-slums-135829. Acesso em: 11/04/2020.

SANDES, A. Brasil é $5^{\circ}$ país do mundo a registrar mais de mil mortes de covid em um dia. UOL, 19/05/2020. Disponível em: https://noticias.uol.com.br/saude/ultimas-noticias/redacao/2020/05/19/brasil-e-o-5-pais-do-mundo-a-registrar-mil-mortes-de-covid-19-em-umdia.htm?cmpid=copiaecola. Acesso em: 19/05/2020.

SANTIAGO, H. Desempregados da periferia. UOL, 24/05/2020. Disponível em: https://economia.uol.com.br/reportagens-especiais/desempregados-periferia-coronavirus/\#desempregadosda-periferia. Acesso em: 25/05/2020.

SANTOS, B. S. A cruel pedagogia do vírus. São Paulo: Boitempo, 2020.

SCHAMA, S. Plague time: Simon Schama on what history tells us. Financial Times, 2020. Disponível em: https://www.ft.com/content/279dee4a-740b-11ea-95fe-fcd274e920ca. Acesso em: 11/04/2020.

SIGNORELLI, A. D. Pandemia e panopticon. /I Tascabile, 2020. Disponível em: https://www.iltascabile.com/societa/pandemia-e-panopticon/. Acesso em: 16/04/2020.

SILVEIRA, S. A. Capitalismo de vigilância. A terra é redonda, 2020. Disponível em: https://aterraeredonda.com.br/capitalismo-de-vigilancia/. Acesso em: 11/04/2020.

SLINGS, S. R. Platonis Rempvblicam, recognovit brevique adnotatione critica instrvxit: S. R. Slings. Oxford: Oxford University Press, 2003.

SMITH, Adam. A Riqueza das Nações. Rio de Janeiro: Nova Fronteira, 2017. (Ebook)

SOJA, petróleo e ferro: coronavírus derruba valor de commodities do Brasil. Exame, 10/02/2020. Disponivel em: https://exame.abril.com.br/economia/soja-petroleo-e-ferro-coronavirus-derrubapreco-de-commodities-do-brasil/. Acesso em: 22/04/2020.

STOLLER, M. The coronavirus relief bill could turn into a corporate coup if we aren't careful. The Guardian, 2020. Disponível em: https://www.theguardian.com/commentisfree/2020/mar/22/coronavirus-relief-bill-corporate-coup. Acesso em: 16/04/2020.

STROPASOLAS, P. Solidariedade do MST busca mostrar que o inimigo, além do vírus, é o capitalismo. Brasil de Fato, 2020. Disponível em: https://www.brasildefato.com.br/2020/04/09/solidariedade-do-mst-busca-mostrar-que-o-inimigo-alem-do-virus-e-o-capitalismo. Acesso em: 11/04/2020. 
SWEEZY, P. M. Monopoly Capitalism. Monthly Review, 2020. Disponível em: https://monthlyreview.org/2004/10/01/monopoly-capitalism/. Acesso em: 14/04/2020.

TALIANO, M. Fitting Together the Pieces of the Coronavirus Puzzle. Global Research, 2020. Disponível em: https://www.globalresearch.ca/fitting-together-pieces-puzzle/5709379. Acesso em : 16/04/2020.

TEWARI, A. Begin from the Beginning: Revisiting Agamben (Critique in times of Corona). Critical Legal Thinking, 2020. Disponível em: https://criticallegalthinking.com/2020/04/09/begin-from-thebeginning-revisiting-agamben-critique-in-times-of-corona/. Acesso em: 12/04/2020.

THE EDITORIAL BOARD. Virus lays bare the frailty of the social contract. Financial Times, 2020. Disponível em: https://www.ft.com/content/7eff769a-74dd-11ea-95fe-fcd274e920ca. Acesso em: 12/04/2020.

THE FOUNDATIONAL ECONOMY COLLECTIVE. After the pandemic: a ten-point plan for the collective provision of basic needs. Open Democracy, 2020. Disponivel em: https://www.opendemocracy.net/en/oureconomy/after-pandemic-ten-point-plan-collective-provision-basic-needs/. Acesso em: 11/04/2020.

TONBY, O.; WOETZEL, J. Could the next normal emerge from Asia? McKinsey \& Company, 2020. Disponivel em: https://www.mckinsey.com/featured-insights/asia-pacific/could-the-next-normalemerge-from-asia. Acesso em: 27/04/2020.

TORERO, M. Without food, there can be no exit from the pandemic. Nature, 23/04/2020. Disponível em: https://www.nature.com/articles/d41586-020-01181-3. Acesso em: 18/05/2020.

TOURAINE, A. Alain Touraine: "Choque econômico do coronavírus pode produzir reações fascistas". Entrevista concedida a Marc Bassets. El País, 2020. Disponível em: https://brasil.elpais.com/ideas/2020-03-31/alain-touraine-choque-economico-do-coronavirus-pode-produzir-reacoes-fascistas.html. Acesso em: 16/04/2020.

VASQUEZ, R. Petróleo WTI para maio fecha em queda sem precedente de $300 \%$ e preço negativo. Valor, 20/04/2020. Disponível em: https://valorinveste.globo.com/mercados/internacional-ecommodities/noticia/2020/04/20/petrleo-wti-para-maio-fecha-em-queda-sem-precedente-de300-pontos-percentuais-e-preo-negativo.ghtml. Acesso em: 22/04/2020.

VASQUEZ, R. Ouro retoma rali e tem maior alta diária em 11 anos. Valor, 24/03/2020. Disponível em: https://valorinveste.globo.com/mercados/internacional-e-commodities/noticia/2020/03/ 24/ouro-retoma-rali-e-tem-maior-alta-diria-em-11-anos.ghtml. Acesso em: 22/04/2020.

WALKER, S. Authoritarian leaders may use Covid-19 crisis to tighten their grip. The Guardian, 31/03/2020. Disponível em: https://www.theguardian.com/world/2020/mar/31/coronavirus-isa-chance-for-authoritarian-leaders-to-tighten-their-grip. Acesso em: 01/05/2020.

WALLACE, R. at al. COVID-19 and Circuits of Capital. Monthly Review, 2020. Disponível em: https://monthlyreview.org/2020/04/01/covid-19-and-circuits-of-capital/?utm_source=rss\&utm_ medium=rss\&utm_campaign=covid-19-and-circuits-of-capital. Acesso em: 17/04/2020.

WALLACE, R. Grandes Fazendas produzem Grandes Gripes. Entrevista concedida a Marx21. Facção Científica, 2020. Disponível em: https://faccaoficticia.noblogs.org/post/2020/04/14/grandesfazendas/. Acesso em: 18/04/2020.

WHYTE, J. Human Rights and Neoliberalism in a Time of Pandemic: A Reply. Legal Form, 2020. Disponível em: https://legalform.blog/2020/04/10/human-rights-and-neoliberalism-in-a-time-ofpandemic-a-reply-jessica-whyte/. Acesso em: 14/04/2020. 
WORLD HEALTH ORGANIZATION. Coronavirus disease 2019 (COVID-19) Situation Report - 85. WHO, 2020. Disponível em: https://www.who.int/docs/default-source/coronaviruse/situation-reports/20200414-sitrep-85-covid-19.pdf?sfvrsn=7b8629bb_4. Acesso em: 14/04/2020.

YINENG, C. On China's 'Color Codes' and Life After COVID-19. Sixth Tone, 2020. Disponivel em: http://www.sixthtone.com/news/1005452/on-chinas-color-codes-and-life-after-covid-19. Acesso em: 14/04/2020.

YOSHIDA, E. et al. Abilio, Karnal, Nizan - o novo mundo pós-pandemia. Exame, 2020. Disponível em: https://exame.abril.com.br/revista-exame/um-novo-mundo/. Acesso em: 16/04/2020.

YUEN, J. Aliens and Alienation: On extraterrestrial thinking in apocalyptic times. The Baffler, 2020. Disponível em: https://thebaffler.com/latest/aliens-and-alienation-eisen. Acesso em: 14/04/ 2020.

ZEROFSKY, E. How Viktor Orbán Used the Coronavirus to Seize More Power. The New Yorker, 09/04/2020. Disponível em: https://www.newyorker.com/news/letter-from-europe/how-viktor-orban-used-the-coronavirus-to-seize-more-power. Acesso em: 23/05/2020.

ZIMMERMANN, J. Corona in 5G. International Politics and Society, 23/04/2020. Disponível em: https://www.ips-journal.eu/regions/europe/article/show/corona-in-5g-4297/. Acesso em: 07/05/ 2020.

ZIZEK, S. Pandemia: Covid-19 e a reinvenção do comunismo. São Paulo: Boitempo, 2020a.

ZIZEK, S. Podemos vencer as cidades pós-humanas. Outras Palavras, 2020b. Disponível em: https://outraspalavras.net/tecnologiaemdisputa/zizek-podemos-vencer-as-cidades-pos-humanas/. Acesso em: 24/05/2020.

Artigo recebido em: 25 de maio de 2020

Artigo aceito em: 10 de julho de 2020 